\title{
Reference Books of 1973-74: A Selection
}

This list initiates a series which will identify works on Slavic and East European topics suitable for inclusion in the reference collections of university libraries and of interest to scholars in the field. Books have been examined by librarians on the staff of the Slavic and East European Division of the University of Illinois Library at Urbana-Champaign and annotations are signed with their initials. ${ }^{1}$ Some of these books may also be the subject of regular reviews in this journal. Because of the large output of significant reference works in the Soviet Union and Eastern Europe, the list is highly selective and, consequently, may lack consistent geographic and subject balance. Library of Congress entries are used when available and Library of Congress card numbers are included to aid in verification.

\section{GeneraL}

Benešová, Sylva. Bibliografie praci $z$ oboru porovnávacího studia slovanských jazyki. Bibliografia rabot po sopostavitel'nomu izucheniiu slavianskikh iazykov. Prague: Kabinet cizích jazykù Ceskoslovenské akademie věd, 1973. ix, 239 pp. LC 74-305312.

1. Marianna Tax Choldin, Danuta Gorecki (Catalog Department), Harold Leich, Laurence H. Miller, June E. Pachuta, Dmytro M. Shtohryn, Gary Wiggins.
Citations to 2,230 items, primarily in the periodical literature, published in Czechoslovakia from 1945 to 1972 and from 1960-72 elsewhere, and dealing with comparative and contrastive analysis of the Slavic languages are contained in this bibliography. Emphasis is on works treating comparison of Russian with other Slavic and non-Slavic languages. Some of the entries are annotated, and the work contains an author and language index.-HL.

Bibliografia polskich prac z zakresu slawistyki. 2 vols. Edited by Jadwiga Czachowska and Jadwiga Puzynina. Warsaw: Państwowe Wydawnictwo Naukowe, 1973. 100 zł. LC 73-222404.

This bibliography consists of 8,578 items, including books, reviews, and articles from about four hundred periodicals and annuals, written by Polish authors and published between 1968 and 1972 in the fields of Slavic language, linguistics, literatures, ethnography, and folklore. Scholarly, rather than popular or pedagogic, publications are emphasized. The bibliography is divided into several broad subject areas and includes an index of personal names.-HL.

Bulgaria

Georgieva, Sonia. Bibliografiia na bŭlgarskata arkheologiia, 1879_ 1966. By Sonia Georgieva and 
Velizar Velkov. 2nd rev. and enl. ed. Bŭlgarska akademiia na naukite. Arkheologicheski institut. Tsentralna biblioteka. Sofia: Izdatelstvo na Bŭlgarskata akademiia na naukite, 1974. 478 pp. 6.84 lv. LC 75-58335.

The first edition (1957) covered the literature through 1955 and had 6,305 entries. The new edition contains 9,523 entries for books and articles and includes citations to reviews. Arranged mainly by chronological period, there are separate sections on epigraphy, numismatics, museology, and other topics.-LHM.

\section{Czechoslovakia}

Vopravil, Jaroslav. Slovnik pseudonymù v české a slovenské literatǔre. Prague: Státní Pedagogické Nákladatelství, 1973. 1540 pp. Kčs. 115.

Over 30,000 pseudonyms of approximately 10,000 Czech and Slovak authors writing in all fields are included in this new reference work which covers pseudonyms from books, pamphlets and periodical articles published through 1965. The work takes a broad view of pseudonyms and includes anagrams, cryptograms, non-alphabetical symbols, and changed names and variant forms of names. Arranged in two parts, the entries in the first part of the dictionary refer the user to the "real" name in part 2. Entries in the second part provide basic biographical data about the authors and a list of all identifiable pseudonyms used by them. Bibliographical references pertaining to the identification and resolution of pseudonyms accompany each entry.-HL.

\section{HUNGARY}

Bako, Elemer. Guide to Hungarian Studies. 2 vols. Hoover Institution Bibliographic Series, 52. Stanford: Hoover Institution Press, 1973. xv, 1218 pp. LC 79-152422.

This selective bibliographic guide to reference works, periodicals, pamphlets, and other material in Hungarian and Western languages relating to Hungarian history, society, culture, and economics contains over 4,400 items published before 1966, many of them annotated. The guide is arranged in twenty broad subject areas. English translations are provided for Hungarian titles. The work includes a personal name index and an index of periodical and other serial titles.-GW.

\section{Poland}

Polski czyn zbrojny w II zwojnie śrviatowej. Vol. 6. Bibliografia wojny wyzwoleńczej narodu polskiego 1939-1945: Problematyka wojskowa; materiaty z lat 1939. 1967. Edited by Krystyna Szczepańska and Bożena Zielińska. Wojskowy Instytut Historyczny. Warsaw: Wydawnictwo Minister- 
stwa Obrony Narodowej, 1973. 832 pp. 120 zł. LC 74-200327.

Included in this revised and greatly enlarged version of Bibliografia wojskowa II wojny szeiatowej: Materialy za lata 1939-1958: Częśś polska, published in 1960 (Horecky, East Central Europe, item 2796) are 8,941 partly annotated entries for books, parts of books, and articles from more than seven hundred periodical titles. The index is one hundred pages long and includes personal and geographical names and titles of anonymous works.-LHM.

\section{Stownik biograficzny teatru polskiego,} 1765-1965. Na podstawie materiałow Stanisława Dąbrowskiego. Edited by Zbigniew Raszewski. Warsaw: Państwowe Wydawnictwo Naukowe, 1973. 905 pp. 320 zk. LC 74-209292.

The 6,298 entries provide an excellent source of historical information on people connected with Polish theater, opera, operetta, and ballet. Included are actors, singers, dancers, directors, set designers, and various other contributors to this area of Polish culture who lived between 1765 and 1965. (The year 1765, when the Teatr Wielki was founded in Warsaw, marks the beginning of acting as a profession in Poland.) Entries include biographical data, description of professional achievements, and illustrations (if available). At the end is a list of plays, ballets, operas, and operettas performed on the Polish stage. The dictionary is based on published and unpublished materials from about 1800 to the present time. The bibliographical apparatus is excellent. This is the first volume of a projected series; supplements are planned every five years. $-D G$.

\section{Russia and Soviet Union}

Biblioteki SSSR: Spravochnik. 2 vols. Gosudarstvennaia biblioteka SSSR imeni V. I. Lenina. Moscow: "Kniga," 1973-74. Vol. 1: Biblioteki RSFSR. 1974. 431 pp. 2.27 rubles. Vol. 2: Biblioteki soiuznykh respublik (bez RSFSR). 1973. 368 pp. 1.96 rubles. LC 74-329753.

The first volume includes 1,927 libraries and updates three directories published from 1964 to 1967 devoted to Moscow, Leningrad, and RSFSR libraries outside Moscow and Leningrad. Volume 2, listing 1,727 institutions, provides the first unified coverage of significant libraries in the other Union Republics. Within each republic, libraries are listed by type and special libraries are arranged by subject. Except for the obvious omission of the names of individual librarians, typical directory information is provided, including size of collections, subject emphases, special collections, catalogues, and services.-LHM.

Kanet, Roger E. Soviet and East European Foreign Policy: A Bibli- 
ography of English \& RussianLanguage Publications 1967-1971. Santa Barbara, Calif.: ABC-Clio, 1974. xvi, 208 pp. \$15.75. LC 7376444.

Kanet lists 3,237 books and periodical articles. Items published in East European countries outside the Soviet Union are not included, but complete coverage is attempted of other non-Soviet titles in English and Soviet works in Russian or English. The arrangement is alphabetical by author and the index is mainly geographical and topical.-LHM.

Muratova, Kseniia Dmitrievna. Bibliografia literatury ob $A$. N. Ostrovskom, 1847-1917. Leningrad: “Nauka," 1974. 284 pp. 1.89 rubles. LC 75-558241.

K. Muratova's latest contribution to literary bibliography concerns the life and works of the playwright A. N. Ostrovskii. The 6,021 citations, listed chronologically and divided within each year by newspaper articles, journal articles, and books, refer to items which are wholly, or in large part, about Ostrovskii. Passing references are not listed, nor are anecdotal materials, program notes, reprints and excerpts from journal articles, and ephemera. Also excluded are citations from provincial publications. Access to the citations is made through three indexes: the first, a list of Ostrovskii's plays (with subdivisions for the major theaters which produced them); the second, a list of additional theaters, societies, and so forth; and the third, a name index. There is also a list of journals and newspapers examined. The bibliography is quite thorough, and the chronological format facilitates the study of changes in attitude toward his work and its influence on the Russian theater over seven decades. -JEP.

Russia (1923-USSR). Tsentral'noe statisticheskoe upravlenie. Itogi $V$ sesoiuznoi perepisi naseleniia 1970 goda. 7 vols. Moscow: "Statistika," 1972-74. Vol. 1: Chislennost' naseleniia SSSR, soiuznykh $i$ avtonomnykh respublik, kraev $i$ oblastei. 1972. 83 kopecks. Vol. 2: Pol, vozrast $i$ sostoianie $v$ brake naseleniia SSSR, soiuznykh $i$ avtonomnykh respublik, kraev i oblastei. 1972. 1.17 rubles. Vol. 3: Uroven' obrazovaniia naseleniia SSSR, soiuznykh $i$ avtonomnykh respublik, kraev $i$ oblastei. 1972. 2.31 rubles. Vol. 4: Natsional'nyi sostav naseleniia SSSR, soiuznykh $i$ avtonomnykh respublik, kraev, oblastei $i$ natsional'nykh okrugov. 1973. 2.68 rubles. Vol. 5: Raspredelenie naseleniia SSSR, soiuznykh $i$ avtonomnykh respublik, kraev $i$ oblastei po obshchestvennym gruppam, istochnikam sredstv sushchestvovaniia $i$ otrasliam narodnogo khoziaistva. 1973. 1.25 rubles. Vol. 6: Raspredelenie naseleniia SSSR i soiuznykh respublik po zaniatiam. 1973. 3.29 rubles. Vol. 7 : Migratsiia naseleniia, chislo $i$ sostav semei $v$ SSSR, 
soiuznykh $i$ avtonomnykh respublikakh, kraiakh i oblastiakh. 1974. 1.83 rubles. LC 73-311438.

The official presentation of 1970 census data is now complete.-GW.

Simmons, John Simon Gabriel. Russian bibliography, libraries and archives: A selective list of bibliographical references for students of Russian history, literature, political, social and philosophical thought, theology and linguistics. Twickenham, Middlesex, England: Anthony C. Hall, 1973. 76 pp. $£ 1.15$. LC 74-162047.

J. S. G. Simmons's book lists, compiled over more than twenty years for his course on Russian bibliography at Oxford University, are now available in printed form. Included are approximately 700 bibliographic works in the areas indicated in the title, as well as general bibliographies and reference works. Reprints (both published and announced) are noted, and locations in British or U.S. libraries are given for most items. Simmons has examined all items in British, Soviet, or U.S. libraries and described them de visu. His book is an invaluable reference and research tool for students of Russia. This edition is out of print; a new, enlarged edition is planned for early 1976.MTC.

Slovar' avtobiograficheskoi trilogii $M$. Gor'kogo: $V$ shesti vypuskakh s prilozheniiam slovaria imen sob- stvennykh. Vol. 1: A-Vsevidiashchii. Leningrad: Izdatel'stvo Leningradskogo universiteta, 1974. 1.45 rubles. LC 75-558417.

Based on the lexicographical theories of B. A. Larin, this set is the first of a long-range project to produce a complete dictionary of Gorky's works. All words found in the trilogy are to be included, with quotations taken from volume 13 of the Sobranie sochinenii v 30-ti tomakh (Moscow: "Goslitizdat," 1949-55). Any variations between that edition and the Polnoe sobranie sochinenii (1968-) are noted in the text.-GW.

Zernov, Nicolas. Russkie pisateli emigratsii: Biograficheskie svedeniia $i$ bibliografia ikh knig po bogosloviuu, religioznoi filosofii, tserkovnoi istorii $i$ pravoslavnoi kul'ture, 1921-1972. Boston: G. K. Hall, 1973. 182 pp. \$19.50. LC 73-1958.

The scope of this volume is limited to "writers of Russian origin . . . who identify themselves with the Orthodox Church." Literary works, religious poetry, and works reprinted from prerevolutionary editions are excluded, as are articles in periodicals. The introduction which is printed in both Russian and English provides a short survey of the main themes of Russian émigré theologians. In addition to the section of bio-bibliographies, there are also lists of collections of essays, periodicals, and other serial publications of a religious nature-GW. 


\section{UKRAINE}

Slovnyk khudozhnykiv Ukraïny. Edited by M. P. Bazhan. Kiev: Hol. red. Ukr. Rad. Entsiklopedii, 1973. 272 pp. 9.80 rubles. LC 74-321359.

This is one of the most complete dictionaries of artists of the Ukraine published in this century. It includes short bio-bibliographies of artists in almost all fields of the fine arts. Many of the listings are accompanied by portraits of the artists and/or illustrations (some in color) of their works. Arranged alphabetically, the dictionary covers the period from the sixteenth century (Pamvo Berynda, ca. 1550-1632) to the present. In addition to Ukrainians, artists only partly of Ukrainian origin and those who devoted their work in part to the Ukraine are covered, but not included are a number of Ukrainian artists who live and work abroad. The book is, however, predominantly concerned with Soviet Ukrainian artists.-DMS.

\section{YugosLavia}

Narodna biblioteka SR Srbije. Katalog knjiga na jezicima jugoslovenskih naroda, 1519-1867. Edited by Svetislav Durić. Belgrade: Narodna biblioteka SR Srbije, 1973. xix, 537 pp. LC 74-971068.

A catalogue of the Serbian $\mathrm{Na}-$ tional Library's collection of 3,044 books printed between 1519 and 1867 and written in one of the Yugoslav languages (that is, Slovenian, Serbo-
Croatian and Macedonian, their earlier literary representations, and the Yugoslav recensions of Church Slavic) is presented in this volume. Full title page transcription is given for each item and entries are arranged alphabetically by author in Serbian Cyrillic. Eight indexes provide additional access by personal name, title, year of publication, place of publication, publisher and printer. The catalogue also contains numerous facsimiles of title pages and illustrations of many of the works listed. A bibliography of 42 items is included.-HL.

\section{REPRINTS}

Bagrii, Aleksandr Vasil'evich. Formal'nyi metod v literature: Bibliografiia. Leipzig: Zentralantiquariat der Deutschen Demokratischen Republik, 1973. [Vladikavkaz: "Tip. 1-i Vladikavkazskoi arteli invalidov-pechatnikov," 1924.] 268 pp. ODM 50. LC 74-224523.

Originally published in only five hundred copies, Bagrii's work is actually a collection of bibliographic essays which survey the Formalist movement in the first decade of its existence. The essays cover the general theory of Formalist methodology, the early work in poetics, and Formalist studies of individual nineteenth and twentieth century authors.MTC.

Binkevich, E. R. Ustnoe tvorchestvo narodov SSSR: Bibliograficheskii ukazatel'. Leipzig: Zentralanti- 
quariat der Deutschen Demokratischen Republik, 1973. [Moscow, 1940.] 95 pp. ODM 40. LC 74324775 .

Approximately 800 briefly annotated entries are included in this compilation. Popular themes of Soviet songs and poems are treated first, but most of the entries are for Soviet and prerevolutionary scholarly works on more traditional subjects of folklore research. Included are studies of Russian, Ukrainian and Belorussian folklore, as well as works on the oral traditions of the non-Slavic populace. -MTC.

Deiateli revoliutsionnogo dvizheniia v Rossii: Bio-bibliograficheskii slovar': Ot predshestvennikov dekabristov do padeniia tsarizma. 10 vols. in 5. Leipzig: Zentralantiquariat der Deutschen Demokratischen Republik, 1974. [Moscow, 192734.] ODM 750.

The reprint edition is also in five volumes. The original work was incomplete; see the annotation to the original edition in Horecky's Basic Russian Publications, item 56.-MTC.

\section{Dobranitskii, M. Sistematicheskii uka-} zatel' literatury po istorii russkoi revoliutsii. Leipzig: Zentralantiquariat der Deutschen Demokratischen Republik, 1973. [Moscow: Gosizdat, 1926.] ODM 40.

This bibliography lists approximately 3,500 items in Russian and other languages published between 1917 and 1922. Entries are classified under 113 subject headings; there is no index. The preface and classification scheme are published in both Russian and French. A reprint edition is also available from Xerox University Microfilms (OP 38406, $\$ 6.00)$. - MTC.

Golitsyn, Nikolai Nikolaevich, kniaz'. Bibliograficheskii slovar' russkikh pisatel'nits. Leipzig: Zentralantiquariat der Deutschen Demokratischen Republik, 1974. [St. Petersburg: Tipografiia V. S. Balasheva, 1889.] 308 pp. Bound with: Ponomarev, Stepan Ivanovich. Nashi pisatel'nitsy. [St. Petersburg: Tipografiia Imperatorskoi Akademii nauk, 1891.] 78 pp. ODM 105.

Golitsyn gives brief biographical data and lists works by and about 1,286 women writers. This book was also reprinted by Xerox University Microfilms (OP 28180, \$15.00) and by Inter Documentation Company (microfiche, R-5901/2, sFr. 16.). Ponomarev's work is a supplement to Golitsyn's dictionary and includes 419 entries.-MTC.

Sistematicheskii ukazatel' literatury 0 evreiakh na russkom iazyke so vremeni vvedeniia grazhdanskogo shrifta (1708 g.) po dekabre 1889 g. Cambridge: Oriental Research Partners, 1973. [St. Petersburg: "Tipo-litografiia A. E. Landau," 1892.] 568 pp. $£ 8.00$.

Published as a special supplement 
to the journal Voskhod, this bibliography of literature in Russian on the Jews contains 9,579 entries. Reviews and related articles are listed for many items. The reprint publisher mysteriously attributes the compilation of this bibliography to V. I. Mezhov. This work is also available from Inter Documentation Company on microfiche (R-7266/2, sFr. 24.). -MTC.

Khmelevskii, G. Mirovaia imperialisticheskaia voina 1914-1918 gg.: Sistematicheskii ukazatel" knizhnoi $i$ stateinoi voenno-istoricheskoi literatury za 1914-1935 gg. Cambridge: Oriental Research Partners, 1973. [Moscow: Izd. Nauchno-issl. otdela Voen. akademii RKKA im. M. V. Frunze, 1936.] 280 pp. £5.40. LC 74-222548.

Khmelevskii's annotated bibliography contains 1,650 entries.-MTC.

Rubakin, Nikolai Aleksandrovich. Sredi knig: Opyt obzora russkikh knizhnykh bogatstv $v$ sviazi $s$ istoriei nauchno-filosofskikh i literaturno-obshchestvennykh idei. Spravochnoe posobie dlia samoobrazovaniia $i$ dlia sistematizatsii $i$ komplektovaniia obshcheobrazova- tel'nykh bibliotek, a takzhe knizhnykh magazinov. 3 vols. 2nd rev. and enl. ed. Cambridge: Oriental Research Partners, 1973. [Moscow: Knigoizdatel'stvo "Nauka," 1911-15.] £33.00.

An essay by Professor Alfred Erich Senn (University of Wisconsin, Madison), "The Publication of Sredi Knig," introduces this reprint of Rubakin's classic work. A reprint edition is also available from Xerox University Microfilms (OP 28568, $\$ 95.00$ ) and from Inter Documentation Company (microfiche, R-7240/2, $\mathrm{sFr} .82 .50)$.-MTC.

Ul'ianinskii, Dmitrii Vasil'evich. Biblioteka $D . V$. Ul'ianinskogo: Bibliograficheskoe opisanie. 3 vols. Cambridge: Oriental Research Partners, 1974. [Moscow: Sklad izd. v knizhnom magazine T-va M. O. Vol'f, 1912-15.] £33.00.

Professor J. S. G. Simmons of All Souls College, Oxford, has written the preface to this reprint edition. The catalogue contains 4,372 entries and excellent annotations. Xerox University Microfilms has also reprinted Ul'ianinskii's catalogue (OP 18383, $\$ 90.00)$. - MTC. 